\title{
INFLUENCE OF NORMAL LOAD AND COUNTERFACE ROUGHNESS ON MICRO-ABRASION/CORROSION OF AISI 304 IN $1 \mathrm{~N} \mathrm{H}_{2} \mathrm{SO}_{4}$ ENVIRONMENT* $^{*}$
}

\author{
Wilian da Silva Labiapari ${ }^{1}$ \\ Miguel Angel Narvaez Ardila² \\ Marcelo Braga dos Santos ${ }^{3}$ \\ José Daniel Biasoli de Mello ${ }^{4}$
}

\begin{abstract}
Austenitic stainless steels are widely known for their good weldability, excellent mechanical properties for deep drawing and superior corrosion resistance in environments where most of the metals fail. Their uses include many applications subjected to a combination of mechanical and corrosive wear, such as pumps, valves and surgical implants. Although their corrosion resistance has been largely investigated, their resistance to mechanical wear is less studied. In particular, their performance under conditions involving combined corrosive and mechanical wear is not well understood. The aim of this study is to demonstrate the effect of the mechanical component on the electrochemical signal of an anodic polarization curve. A test rig was developed to investigate micro-abrasion-corrosion using a fixed ball configuration. Tests were carried out using stainless steel AISI 304 samples and 25.4 $\mathrm{mm}$ zirconia balls as counter bodies. The electrolyte was a $1 \mathrm{~N} \mathrm{H}_{2} \mathrm{SO}_{4}$ solution with $\mathrm{SiO}_{2}$ as abrasive dispersed at the concentration of $10 \mathrm{wt} \%$. The results showed an increase in current density when the counter face roughness and the normal load applied during the tests are increased, evidencing a mechanical influence on the surface activity of this material in a corrosive environment.
\end{abstract}

Keywords: Abrasion-corrosion; Mechanical influence; AISI 304.

1 M. Sc, Researcher, R\&D, Aperam South America, Timóteo, MG, Brazil.

2 M. Sc, Ph. Dr. candidate, Universidade Federal de Uberlândia, Uberlândia, MG, Brazil.

3 Dr. Eng., Associate professor, Universidade Federal de Uberlândia, Uberlândia, MG, Brazil.

4 Doc. Ing., Emeritus professor, Universidade Federal de Uberlândia, Uberlândia, MG, Brazil.

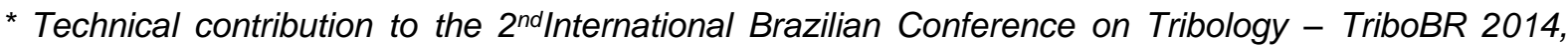
November $3^{\text {rd }}$ to $5^{\text {th }}, 2014$, Foz do Iguaçu, PR, Brazil. 


\section{INTRODUCTION}

Usually the corrosion and abrasion subjects are treated one at a time. There are many studies discussing about environments and materials, or systems, susceptible to the corrosion $[1,2]$ or abrasion phenomena $[3,4]$.

Fifteen years ago, the studies concerning the combined effect began to be more extensively developed. For corrosion studies it is possible to find devoted equipments like potentiostat/galvanostat or salt spray cameras. On the other hand, for wear studies the availability is rare and the best equipments are constructed to simulate specific tribosystem comparing the wear mechanisms present in the sample and in the actual component. Under controlled conditions these equipments provide information, such as the forces involved in the tests, which permits a better understanding of the wear phenomena.

The abrasion-corrosion systems are important to certain engineering areas and bioengineering, wherever both effects are present. Some examples are pumps and valves in the process of oil-gas or marine industry, metallic surgical implants, bone replacing on human body parts [5] and also the sugarcane sector, where there is an abrasive-corrosive system on sugar cane preparation.

Some works performed on abrasion and corrosion separately aiming at understanding the influence of the corrosive environment by mathematical approximation have much dispersion and errors [6]. In order to obtain more accurate results the test should include the combined effect. On this way, it is possible to evaluate in situ and simultaneously both mechanical and electrochemical phenomena, which dispense mathematical approximation of synergistic, antagonistic and additive effects associated to [5]. Therefore, several adaptations have been made at test rigs to study some wear mechanisms combined to a corrosion component. Regarding to the sliding wear, Perret [7] combined a reciprocating tribometer, sphere to plane contact type, with a potentiostat. The objective was to study the stainless steel AISI $304 \mathrm{~L}$ in $0.5 \mathrm{M} \mathrm{H}_{2} \mathrm{SO}_{4}$, by using as counter body an alumina sphere with different load levels. Another interesting study has been performed by Garcia [8] associating a potentiostat to a ball-on-disc tribometer. The purpose was to study the stainless steel AISI 316 with an alumina ball as counter body, varying the load between 2 and $20 \mathrm{~N}$ in a solution of $0.5 \mathrm{M} \mathrm{H}_{2} \mathrm{SO}_{4}$. Gant [9], using $\mathrm{SiO}_{2}(200 \sim 312 \mu \mathrm{m})$ as abrasive in a modified rubber wheel equipment studied the behaviour of the hard metal base $\mathrm{WC}$ at $\mathrm{H}_{2} \mathrm{SO}_{4}(\mathrm{pH} 1.1$ and 2.6) solutions.

Several studies have been measuring corrosion-abrasion of biomaterials and coatings [5]. According to Stack [10], if the surface undergoes chemical attack, this can affect the wear process. To perform the in situ trials with corrosion, microabrasion testing equipment has been adapted.

Stack [10] modified a Phoenix Tribology Tribometer Plint TE-66 to couple a corrosion cell with a potentiostat AC Gill. The applied load level could vary between 0.05 and 5 $\mathrm{N}$ using as counter body a polypropylene ball of $25 \mathrm{~mm}$ diameter rotating between 30 and 150 RPM. Under these settings, it was studied the behaviour of a low carbon steel in corrosive medium of $0.5 \mathrm{M} \mathrm{Na}_{2} \mathrm{CO}_{3}+0.5 \mathrm{M} \mathrm{NaHCO}_{3}$ and $\mathrm{SiC}$ abrasive $(4.0$ $\mu \mathrm{m}$ of diameter) at the concentration of $0.25 \mathrm{~g}_{\mathrm{cm}} \mathrm{cm}^{-3}$ with applied load between 1 and $5 \mathrm{~N}$ and ball rotating at $100 \mathrm{rpm}$. It has been shown that the highest current intensity, or the greatest corrosive effect is due to the highest load level.

Sinnett-Jones [11] adapted to a Phoenix Tribology Tribometer Plint TE-66 a corrosion cell with a Gamry PC-4750 potentiostat to study the stainless steel AISI 304L and the CoCrMo alloys, both used in artificial human joints subject to abrasion and corrosion.

* Technical contribution to the $2^{\text {nd }}$ International Brazilian Conference on Tribology - TriboBR 2014, November3 ${ }^{\text {rd }}$ to $5^{\text {th }}, 2014$, Foz do Iguaçu, PR, Brazil. 


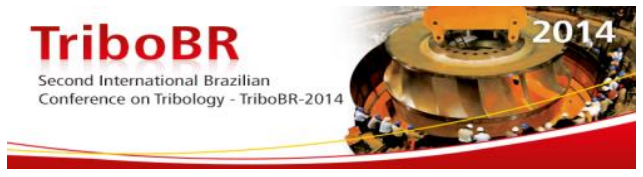

Counter faces balls of $\mathrm{Al}_{2} \mathrm{O}_{3}$ and $\mathrm{CoCrMo}$ with a diameter of 25.8 and $22.0 \mathrm{~mm}$ were used, in the electrolytic medium $\mathrm{NaCl}+\mathrm{KCl}+\mathrm{CaCl}_{2}$ at $\mathrm{pH} 7.6$ (Ringer's solution). The abrasive used was $\mathrm{SiC}$ with $4.5 \mu \mathrm{m}$ concentrated at $0.1 \mathrm{~g}^{\mathrm{cm}} \mathrm{cm}^{-3}$. The abrasivecorrosive tests were performed by constructing polarization curves with potential rate increasing of $2 \mathrm{mV} . \mathrm{s}^{-1}$ and OCP test (Open Circuit Potential) under load $0.25 \mathrm{~N}$. A negative synergy was observed for the couple sample/ball 304/CoCrMo and CoCrMo/ CoCrMo.

Wood [5] used a Phoenix Tribology Tribometer Plint TE-66 adapting a corrosion cell with a Gamry potentiostat. It was used $\mathrm{SiC}$ as abrasive with a diameter of about 4.5 $\mu \mathrm{m}$ in $\mathrm{NaCl} 3.5 \%$. Materials such as duplex stainless steel UNS S32205 were studied, using as counter face a zirconia ball and the load of $0.25 \mathrm{~N}$. The different concentrations of abrasive at electrolytic medium, between 0 and $0.12 \%$ at volume, were used which led to different currents density during the test, i.e., different levels of corrosive component induced by mechanical effect, being higher for the higher concentrations. Due to mechanical wear the passive layer of the material can be broken or removed [12]. Although there is a certain dispersion in the results, most of the fluctuations are attributed to the competition between the removal of the passive layer and the material repassivation phenomenon [5].

Usually, on this kind of test, materials capable to passivating in the studied environment are analysed, so the effect of the corrosion kinetics can be checked under the influence of wear. The equipments settings usually don't allow the deaeration of the electrolyte for the corrosion and abrasion-corrosion test.

The results presented by mechanical versus electrochemical effect seem to be an excellent way to understand and predict the performance of surfaces at different tribo-corrosive systems [5].

The bio energy sector, concerning the sugar and ethanol plants, is an example of environment where the system imposes simultaneously abrasion and corrosion on the used materials. Specifically at the sugar cane preparing place for the extraction of sugarcane juice, the corrosive agent is relatively weak, being mostly water and juice. The abrasive is basically sand, which comes from the field beyond the straw and sugarcane bagasse, being it a moderately both abrasive and corrosive system. In this system, a low chromium ferritic stainless steel has performed in an excellent way. It can be seen in the Figure 1a a carbon steel ASTM A36 used in an equipment in sugar cane preparation for crushing. It can be noticed a yellowish tone due to the corrosion product, as well as surface scratches owing to the abrasive wear. On the other hand, Figure 1b, a stainless steel with $11 \% \mathrm{Cr}$ applied to the same component did not present any corrosion product and after two years presented low wear and a smooth surface [13].
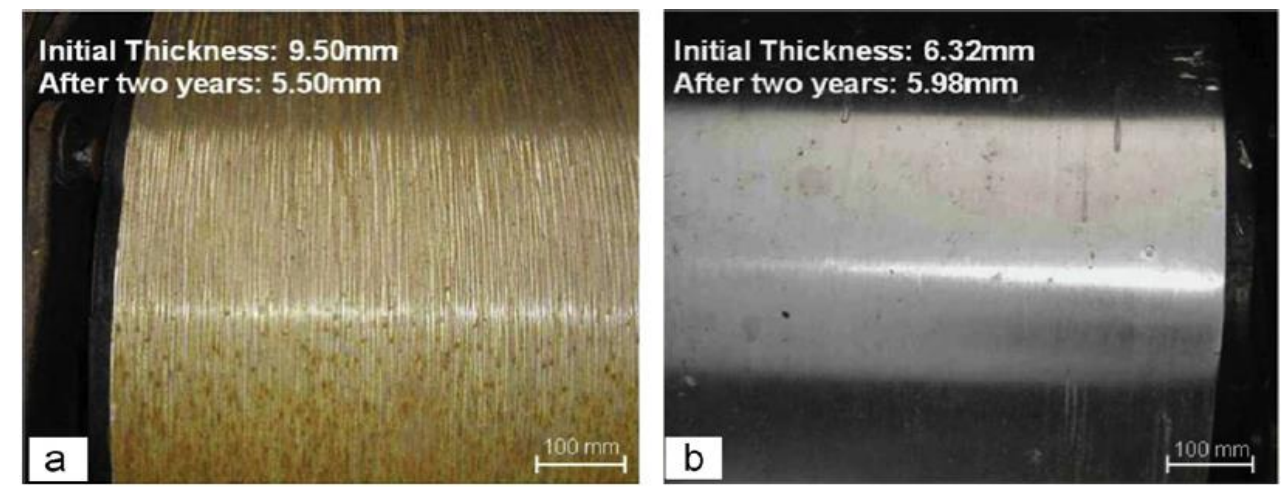

Figure 1 - Worn surfaces in field test after use during two seasons, collected during season: (a) Low carbon steel and (b) low Cr ferritic stainless steel [13].

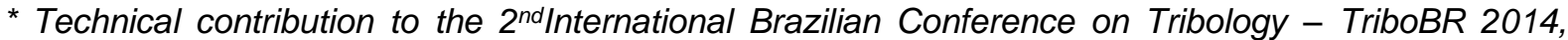
November $3^{r d}$ to $5^{\text {th }}, 2014$, Foz do Iguaçu, PR, Brazil.
} 


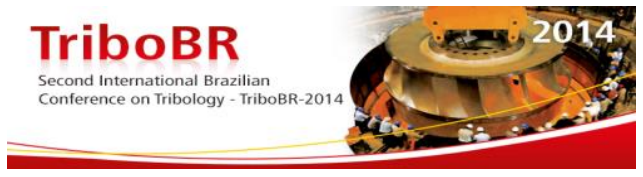

At more aggressive environments, which present higher severity of corrosive component a nobler stainless steel might be required. Therefore, this paper aims at studying the behaviour of a stainless steel AISI 304 at more aggressive abrasivecorrosive ambient, evidencing the influence of the normal load on the polarization curve. It is well known that other agents can change significantly the wear mechanism, such as abrasive concentration evidenced by Adachi [14] during microabrasion tests. So that, this paper also focus on the effect of the ball counter face roughness on the electrochemical signal in the polarization curve.

Since there is not any commercial test rig capable of reaching those objectives it was necessary to design and construct a novel test rig, where abrasion and corrosion occur simultaneously under controlled conditions on the same specimen surface. The equipment consists of a fixed ball test rig for micro-abrasion, with a greater flexibility to apply different normal load levels and load profiles, combined with a potentiostat / galvanostat. Under this configuration it is possible to construct an anodic/cathodic polarization curve during the micro-abrasion test. To measure the scar, it was installed a digital camera system.

\section{MATERIAL AND METHODS}

The study followed the steps shown in Figure 2, where the main activities are described.

(2)

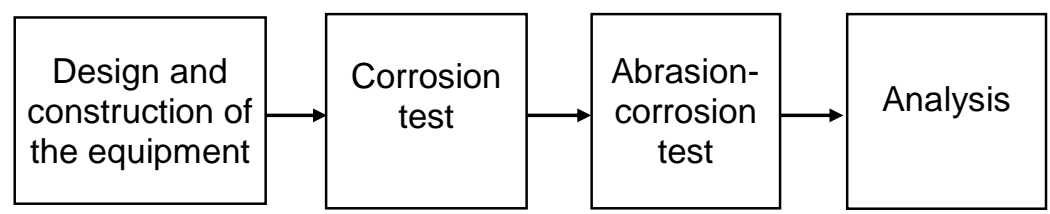

Figure 2 - Main activities flowchart.
(3)

(4)

\section{Step 1}

A hybrid equipment has been designed. Here a potentiostat and a fixed ball test rig for micro-abrasion have been associated. Normal force is applied using dead weights by means of a lever arm system. The relation between the force introduced by the dead weights and the normal force is $1: 1$. The lever system is shown in Figure $3 a$. The specimen and the electrodes, from a potentiostat Biologic model SP-150, are positioned inside an inert and insulated electrochemical cell, Figure $3 b$.
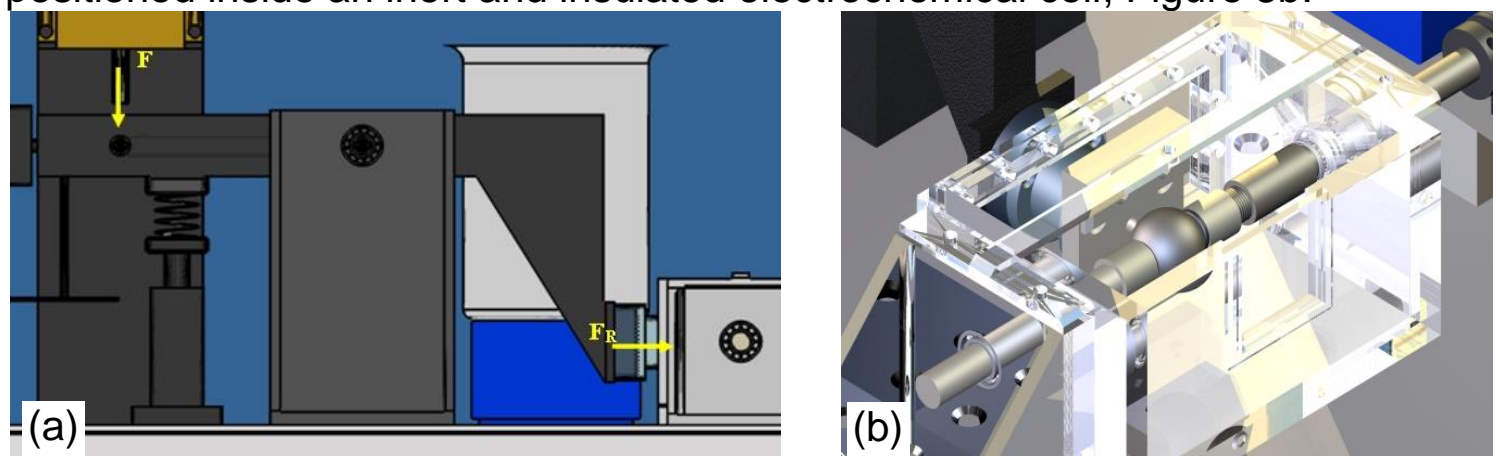

Figure 3 - System with (a) lever force application and (b) the corrosion cell made by inert material to electrolyte solution.

\section{Step 2}

Stainless steel AISI 304 samples had been were cut at dimensions of $35 \times 25 \times 5$ $\mathrm{mm}$, sanded with 220 grit sandpaper and then finished with an 600 grit sandpaper.

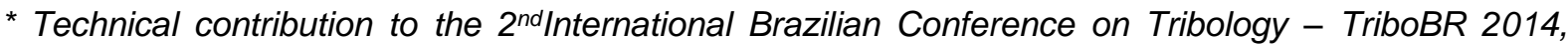
November $3^{r d}$ to $5^{\text {th }}, 2014$, Foz do Iguaçu, PR, Brazil.
} 


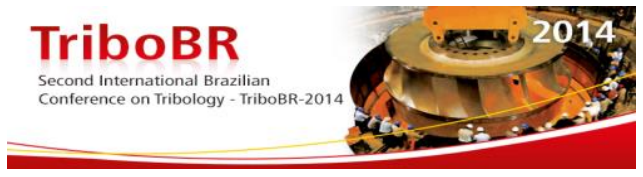

After this step they were subjected to ultrasonic cleaning in acetone during 5 minutes. To delimit the area subjected to corrosion process equal to $2 \mathrm{~cm}^{2}$ it had been used a synthetic enamel. A wire allows the electrical contact. To finalizing the samples preparation, it was used wax to sealing their edges, Figure 4. To ensure result reproducibility, the entire preparation process occurred at least eight hours before its execution.
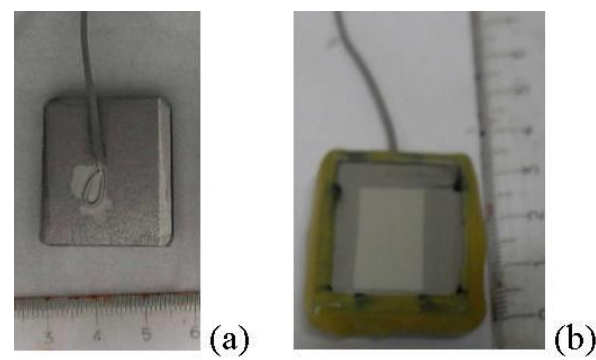

Figure 4 - Sample preparation for abrasion-corrosion test with (a) the fixed wire to allow the electric contact and (b) synthetic enamel and final sealed with wax.

The corrosion tests were performed using a solution of $1 \mathrm{~N} \mathrm{H}_{2} \mathrm{SO}_{4}$. The specimen is partially submerged in the solution. The same solution is pumped at a rate of 1.7 $\mathrm{ml} / \mathrm{min}$ over the exposed area creating a saline bridge, Figure 5 . The anodic polarization curve has been obtained by using a potential increasing at rate of 1 $\mathrm{mV} . \mathrm{s}^{-1}$. At least 3 tests were performed.
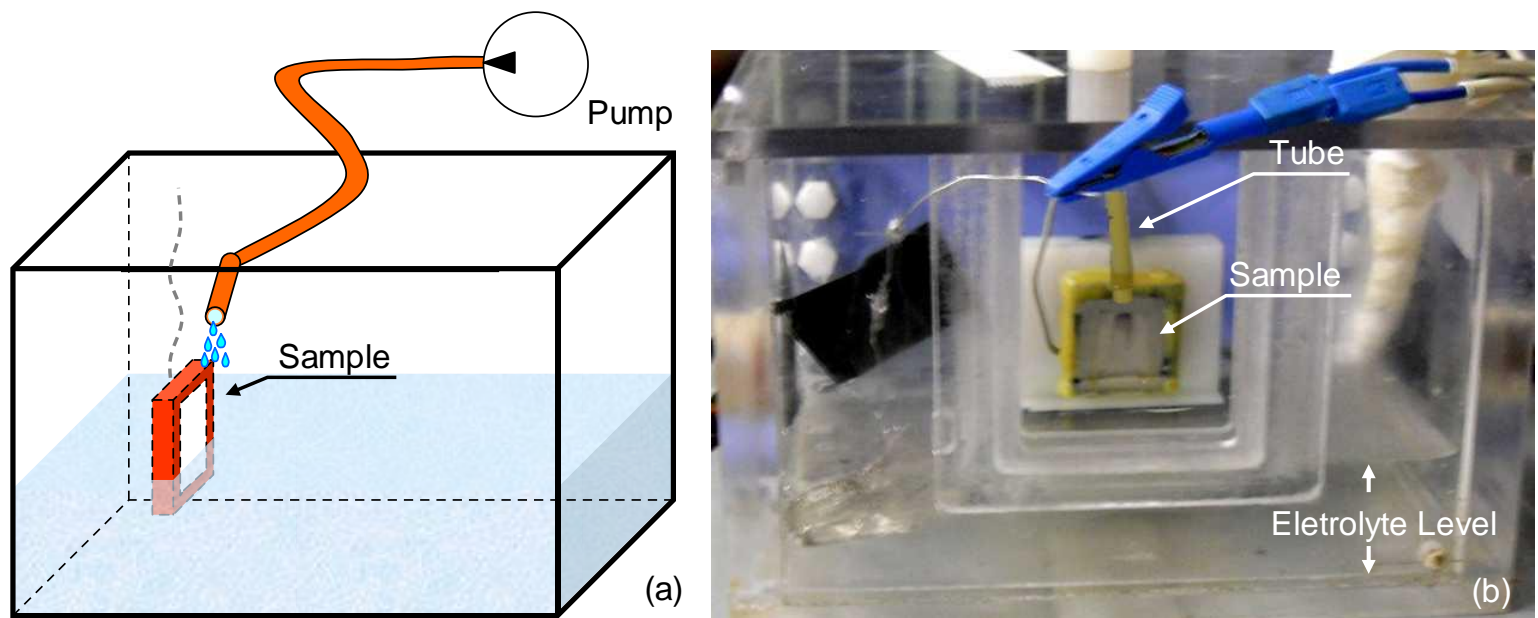

Figure 5 - (a) Schematic setup of the sample and (b) the real condition in corrosion cell.

\section{Step 3}

In order to understand the influence of the counter face roughness in the abrasive wear mechanism the tests were carried out using three different ball roughness: 0.06 $\pm 0.01,0.34 \pm 0.06$ e $0.54 \pm 0.04 \mu \mathrm{m} \mathrm{Ra}$. The tests duration was 15 minutes, with a rotary speed of $150 \mathrm{rpm}$ and $1.42 \mathrm{~N}$ applied normal load. The slurry was fed continuously and its composition was: A mixture of distilled water with 10 wt $\%$ of $\mathrm{SiO}_{2}$ at a rate of $1.7 \mathrm{ml} / \mathrm{min}$.

Abrasion-corrosion tests were performed for 2 different normal loads (0.50 and 1.42 $\mathrm{N})$. It was used as counter body a zirconia ball with a diameter of $25.4 \mathrm{~mm}$ at 150 rpm. Two distinct roughness, $0.20 \pm 0.03$ and $0.34 \pm 0.03 \mu \mathrm{m} \mathrm{Ra}$ were used in combination with the two normal load levels resulting in four different configurations. In this test the slurry composition was an electrolyte of $1 \mathrm{~N} \mathrm{H}_{2} \mathrm{SO}_{4}$ with $10 \mathrm{wt} \% \mathrm{SiO}_{2}$ (5 $\mu \mathrm{m}$ diameter) at a rate of $1.7 \mathrm{ml} / \mathrm{min}$. The steps to this test were:

1. The zirconia ball is placed in contact with the sample, inside the corrosion cell;

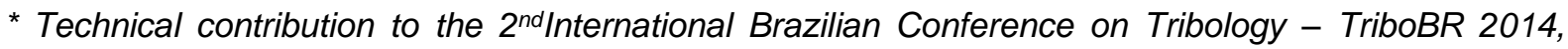
November $3^{r d}$ to $5^{\text {th }}, 2014$, Foz do Iguaçu, PR, Brazil. 


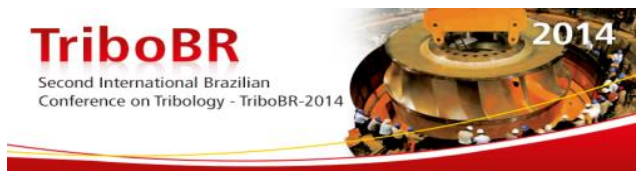

2. It is pumped the abrasive-corrosive solution to the region between the zirconia ball and the sample;

3. It is applied the load by dead weight;

4. It is started the engine speed at $150 \mathrm{rpm}$ for 15 minutes to ensure the formation of the wear scar promoting the mechanically removing the passive film;

5. It is started the polarization curve at cathodic cycle at $-100 \mathrm{mV}$ below the open circuit potential (OCP), ensuring removal of passive layer by electrochemical action, using a potential incensement of $1 \mathrm{mV} . \mathrm{s}^{-1}$.

At least 3 tests were performed for each configuration. The main parameter evaluated was the current in the passive region of the polarization curve.

\section{Step 4}

In this step the samples have been analysed by SEM and optical microscope. The electrochemical signals were analysed in comparison to the SEM images and to the wear scars, which were also measured to indicate the severity damage severity caused on the surface.

\section{RESULTS AND DISCUSSION}

Figure 6 illustrates the influence of the ball surface roughness on the size of the scars. The wear severity increases with the ball surface roughness.
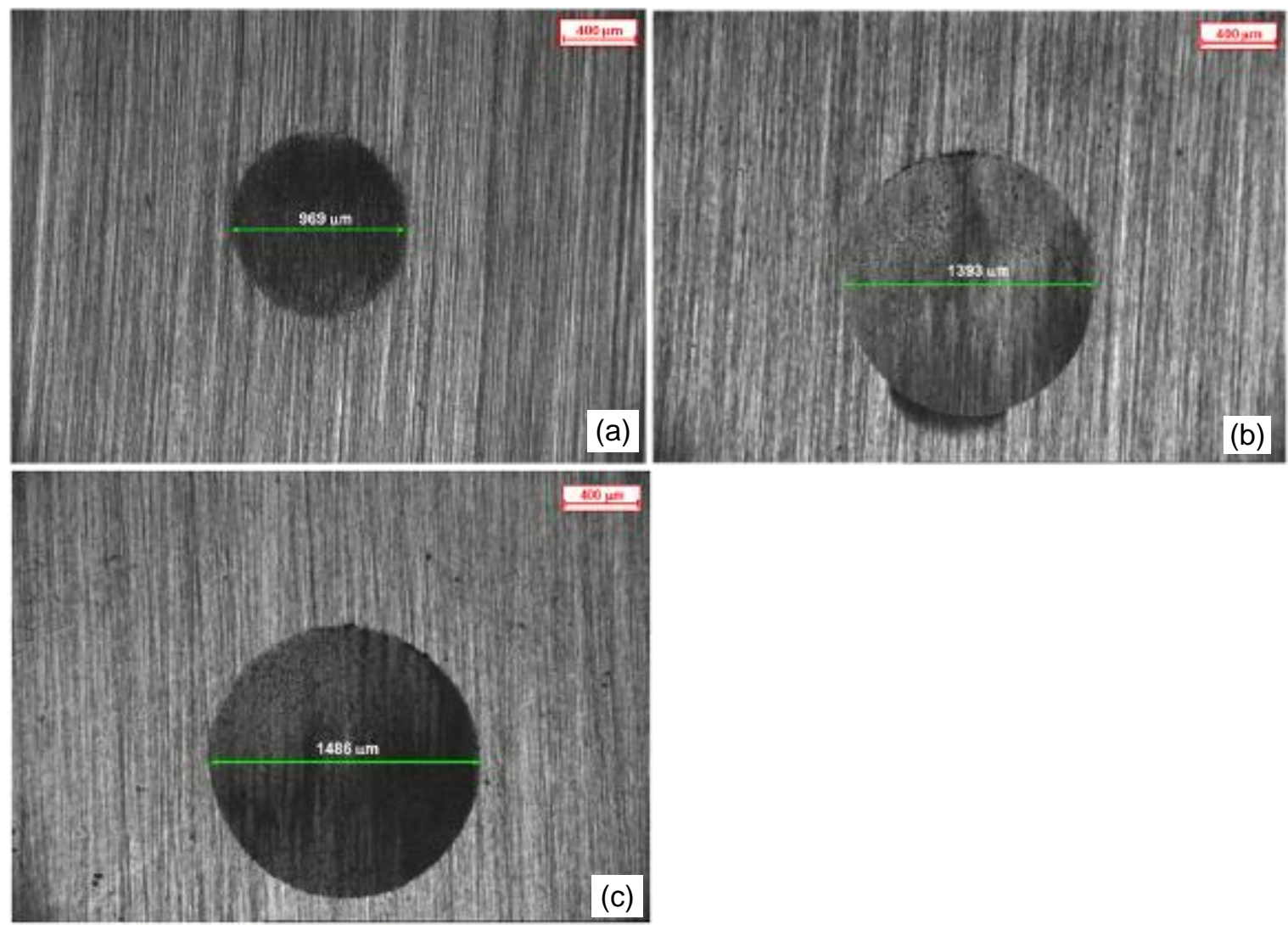

Figure 6 - Influence of ball roughness on wear scars. (a) $R a=0.06 \pm 0.01 \mu \mathrm{m}$. (b) $R a=0.34 \pm 0.06 \mu \mathrm{m}$ (c) $\mathrm{Ra}=0.54 \pm 0.04 \mu \mathrm{m}$.

In addition, the sphere surface roughness had great influence on wear mechanism, particularly the dynamics of the abrasive particles in the interface which changed from particles sliding to particles rolling as the roughness increased. This transition is

* Technical contribution to the $2^{\text {nd }}$ International Brazilian Conference on Tribology - TriboBR 2014, November $3^{r d}$ to $5^{\text {th }}, 2014$, Foz do Iguaçu, PR, Brazil. 
progressive, i.e. in Figure $7 a-b$ it is observed an almost pure sliding mechanism whereas in Figure 7c-d the number of sliding particles reduced the number of rolling particles increased. Finally it is observed in Figure 7e-f that the particles were rolling and the number of particles sliding was negligible. One can observe the predominance of rolling particles with a smooth surface sphere, however for a rough surface the particles tend to slid. A similar effect has been described by Williams and Hyncica [15] and by Trezona el al. [16] which stated that the dynamic condition will govern the particle motion in abrasion tests. They observe that an increase in the normal load promotes small indentation and changes the wear mechanism from sliding to rolling mechanism. A similar phenomenon has been observed when a rough surface sphere is used, i.e., small parts of the particles are positioned inside the craters of the rough surfaces as in the indentations aforementioned.
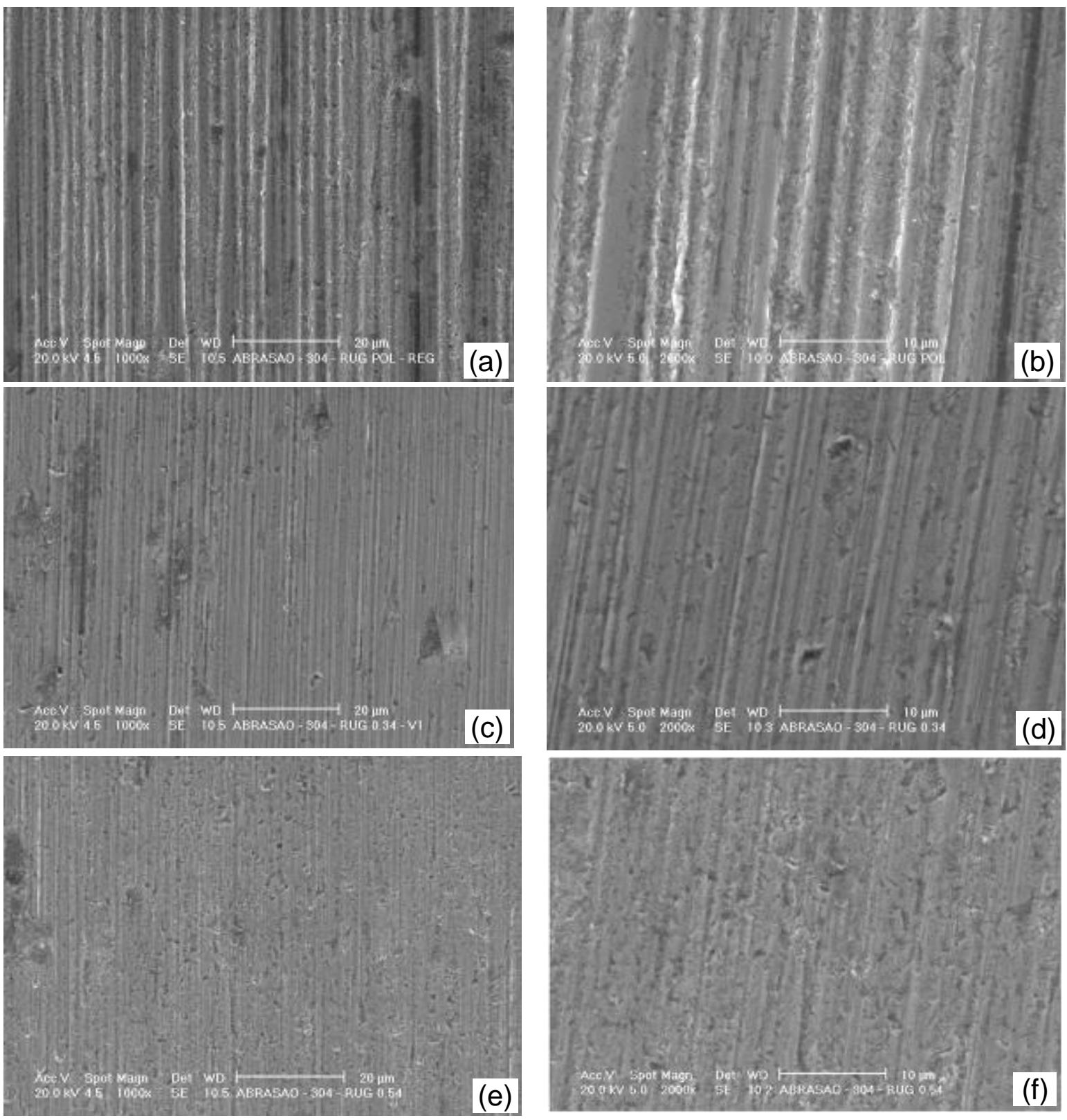

Figure $7-$ Typical aspects of the wear scars. $1.42 \mathrm{~N}$. (a-b) $\mathrm{Ra}=0.06 \pm 0.01 \mu \mathrm{m},(\mathrm{c}-\mathrm{d}) \mathrm{Ra}=0.34 \pm$ $0.06 \mu \mathrm{m}$ e (e-f) $R a=0.54 \pm 0.04 \mu \mathrm{m}$.

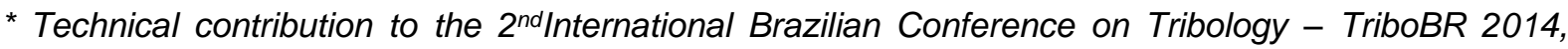
November $3^{\text {rd }}$ to $5^{\text {th }}, 2014$, Foz do Iguaçu, PR, Brazil. 


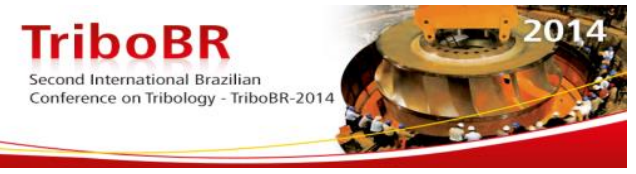

Due to the corrosion cell is fully electrical insulated, and the steel AISI 304 is quite stable in this solution ( $\left.1 \mathrm{~N} \mathrm{H}_{2} \mathrm{SO}_{4}\right)$, the electrochemical signal is very stable and there is little dispersion at the results of polarization curves, in the same test conditions. In Figure 8 it is possible to observe that the current density increases as the normal load increases too, independently of the sphere surface roughness.

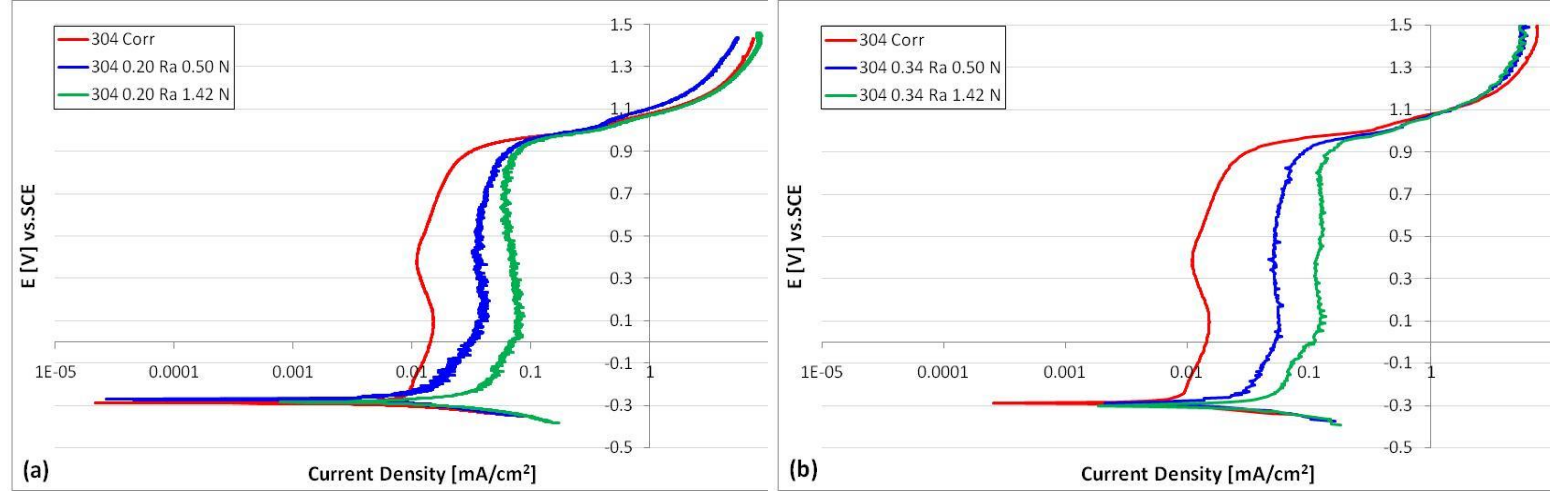

Figure 8 - Corrosion polarization curve $\left(1 \mathrm{~N} \mathrm{H}_{2} \mathrm{SO}_{4}\right)$ and abrasion-corrosion tests $\left(1 \mathrm{~N} \mathrm{H}_{2} \mathrm{SO}_{4}+10\right.$ wt\% $\mathrm{SiO}_{2}$ ).(a) $\mathrm{Ra}=0.20 \pm 0.03 \mu \mathrm{m}$. (b) $\mathrm{Ra}=0.34 \pm 0.03 \mu \mathrm{m}$.

On the other hand, it is observed, in Figure 9, changes in the current density due to the roughness increment. It can be observed the higher current density for the higher roughness of the ball in both load conditions. The Table 1 summarises the current density at the passive region.

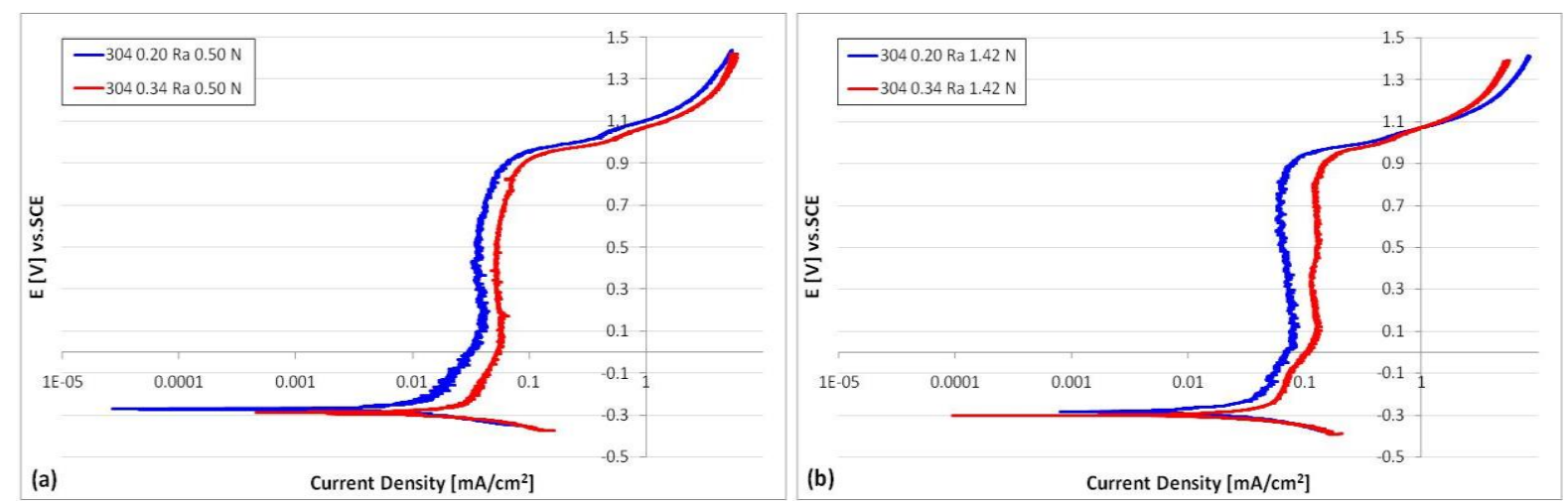

Figure 9 - Polarization curve of abrasion-corrosion tests $\left(1 \mathrm{~N} \mathrm{H}_{2} \mathrm{SO}_{4}+10 \mathrm{wt} \% \mathrm{SiO}_{2}\right)$ on samples of AISI 304 with the roughness of the counter face ball of $\mathrm{Ra} 0.20 \pm 0.03 \mu \mathrm{m} R \mathrm{Ra}$ and $0.34 \pm 0.03 \mu \mathrm{m} \mathrm{Ra}$ at load of (a) 0.50 and (b) $1.42 \mathrm{~N}$.

Table 1 - Passive current density for each condition of corrosion and abrasion-corrosion test

\begin{tabular}{|c|c|c|}
\cline { 2 - 3 } \multicolumn{2}{c|}{} & Current Density $\left[\mathrm{mA} / \mathrm{cm}^{2}\right]$ \\
\hline \multirow{2}{*}{$0.20 \mathrm{Ra}$} & $0.50 \mathrm{~N}$ & $0.013 \pm 0.003$ \\
\cline { 2 - 3 } & $1.42 \mathrm{~N}$ & $0.039 \pm 0.004$ \\
\hline \multirow{2}{*}{$0.34 \mathrm{Ra}$} & $0.50 \mathrm{~N}$ & $0.068 \pm 0.005$ \\
\cline { 2 - 3 } & $1.42 \mathrm{~N}$ & $0.070 \pm 0.014$ \\
\hline
\end{tabular}

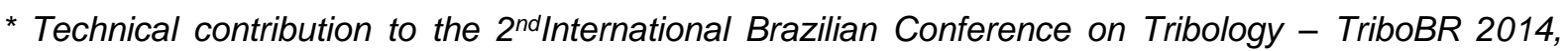
November $3^{r d}$ to $5^{\text {th }}, 2014$, Foz do Iguaçu, PR, Brazil. 
The increase in the current density with the increase of normal load is reported by Stack et al. [17] for micro-abrasion test and by Garcia et al. [8] for sliding-corrosion test, and the authors discuss the level of damage at the passive layer. On the same way, Pei-Qiang et al. [18] associated the increase of the current, under load condition, due to the removal of the passive film and the decrease at current, under the unload condition, owing to the new passive film formation. The increase in the normal load leads to increase the friction force too, which introduces more energy at the contact activating the surface to the corrosion.

Garcia et al [8] used samples of AISI 316 at $0.5 \mathrm{M} \mathrm{H}_{2} \mathrm{SO}_{4}$ environment for sliding tests. According to their results it is possible to observe an increase at the current from approximately 0.75 to $1.5 \mathrm{~mA}$ at $0,83 \mathrm{~Hz}$ for an increase at the load from 5 to 20 $\mathrm{N}$. Stack et al [17] used Ringers solution mixed with SiC particles for micro-abrasioncorrosion tests at samples of $\mathrm{Co}-\mathrm{Cr}$ observed an increase at the passive current from approximately 10-4 to 10-3 mA for an increase of the load from 0.5 to $5 \mathrm{~N}$. Stack et al [10] observed the same behaviour using samples of mild steel at a slurry of silicon carbide with corrosive liquid $\left(0.5 \mathrm{M} \mathrm{Na}_{2} \mathrm{CO} 3 \mathrm{C}+0.5 \mathrm{M} \mathrm{NaHCO}_{3}\right)$ for microabrasion-corrosion tests. Increasing the load from 1 to $5 \mathrm{~N}$ increases the passive current from approximately 10-1 to $100 \mathrm{~mA}$.

Evaluating the wear scars formed during the tests, Figure 10a and 10b, it can be noticed that the bigger scars occurred for the higher loads. It is possible to see in Figures $10 \mathrm{c}$ and $9 \mathrm{e}$ a predominance of sliding particles. Instead, it is verified in Figures $10 \mathrm{~d}$ and $10 \mathrm{f}$ that the number of particles sliding is quite low and the wear mechanism is consequence of a major part of the rolling particles.

The phenomena described for the pure abrasion test, which relates the roughness of the counter body with the wear mechanism, is verified again in the Figure 11. In this case it was observed that the roughness is a sufficient condition to roll the particles, no matter what the level of the normal force is.

With load increased, and also the ball roughness, there is an increase in the current density. As quoted by Thakare [12], due to a strain or mechanical wear, the passive layer of the material can be either fractured or removed. Increasing the surface stress with a higher normal load activates the surface, which results in a higher current density, therefore, facilitates the corrosion process. As postulated by Bello [6] in terms of synergistic effects, the most significant results are obtained when the wear mechanism is due to rolling particles, the same mechanism found predominantly in the scars observed in this study. It can also be seen that in the condition of this study, increasing the roughness of the zirconia ball counter face has promoted an increase in wear, producing greater active area which is susceptible to corrosion.

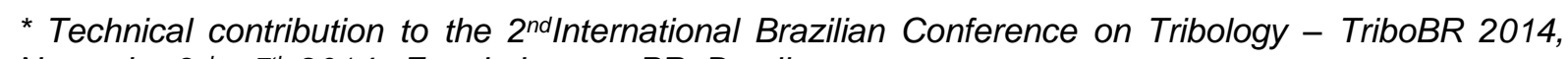
November3 ${ }^{\text {rd }}$ to $5^{\text {th }}, 2014$, Foz do Iguaçu, PR, Brazil. 

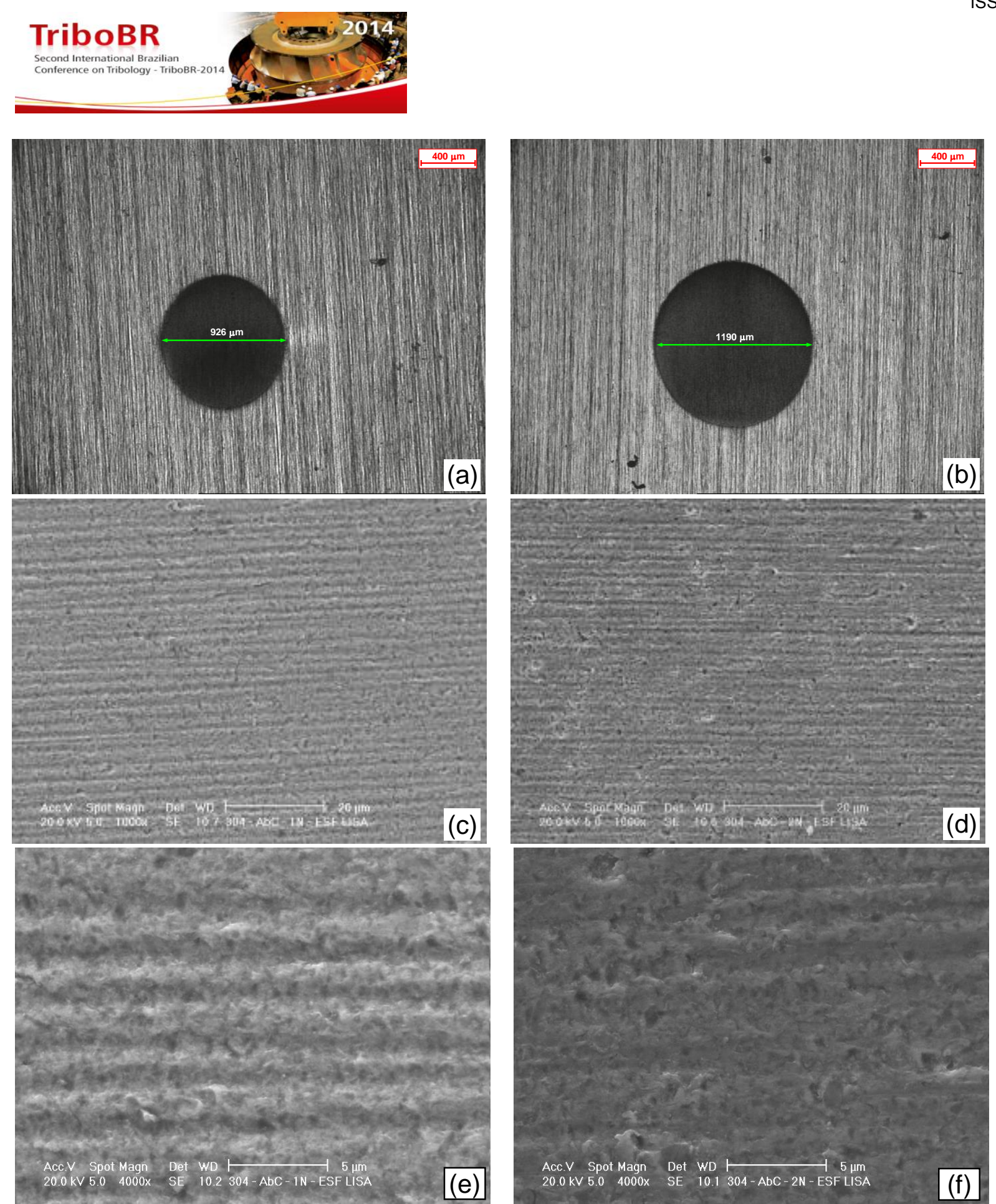

Figure 10 - Analysis of formed scars in the abrasion-corrosion tests using the ball with the roughness of $0.20 \mu \mathrm{m} \mathrm{Ra}$ at loads of (a) (c) (d) 0.50 and (b) (d) (f) $1.42 \mathrm{~N}$.

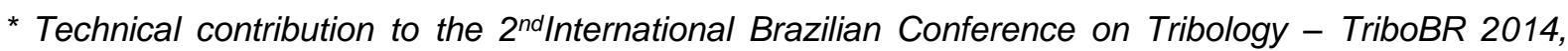
November $3^{\text {rd }}$ to $5^{\text {th }}, 2014$, Foz do Iguaçu, PR, Brazil. 

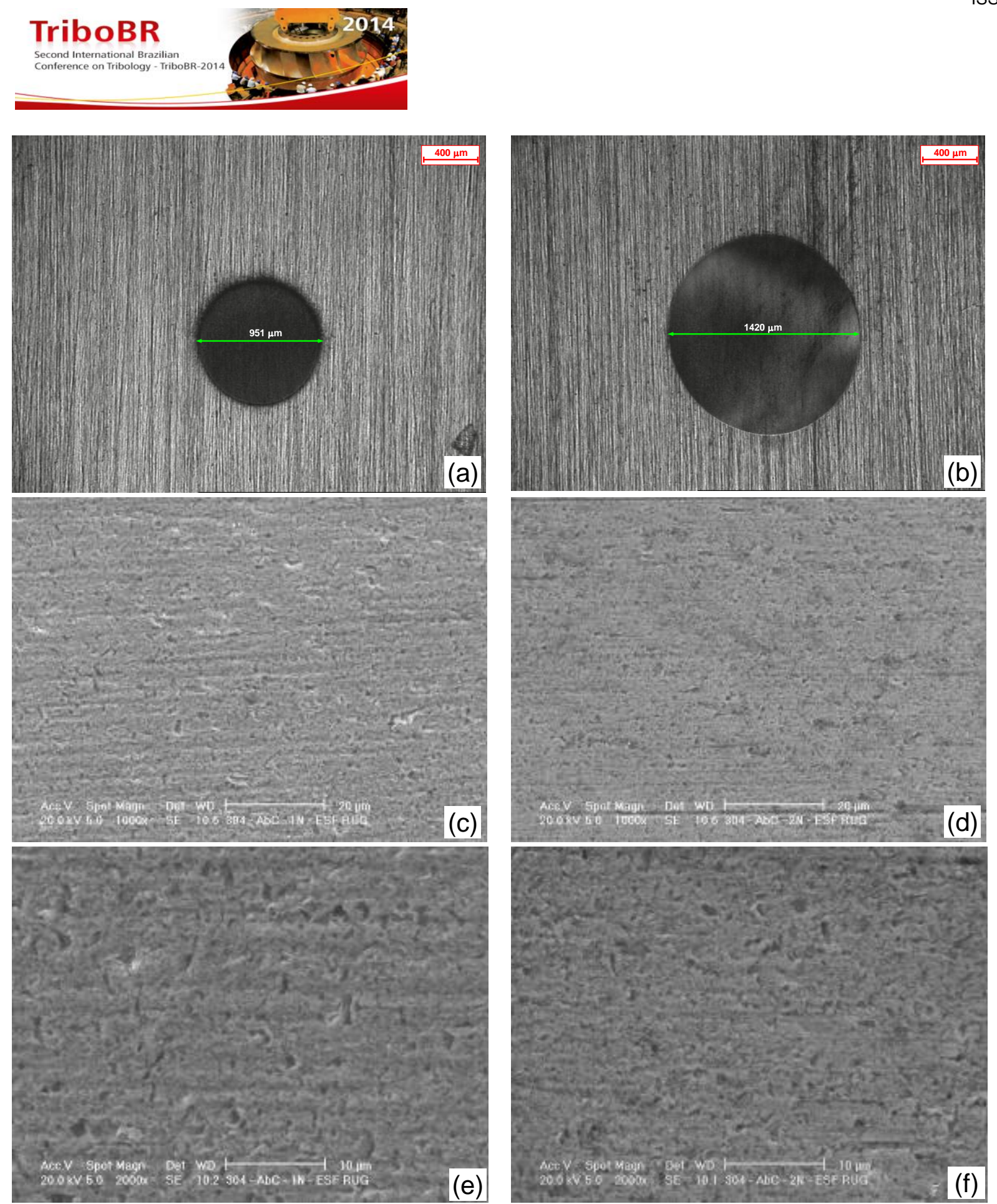

Figure 11 - Analysis of formed scars in the abrasion-corrosion tests using the ball with the roughness of $0.34 \mu \mathrm{m}$ Ra at loads of (a) (c) (d) 0.50 and (b) (d) (f) $1.42 \mathrm{~N}$.

\section{CONCLUSIONS}

The increment in the surface stress, produced by higher normal load, implies on energy increase to be dissipated at the surface as friction force. This is responsible for the remotion of the passive layer exposing a virgin surface to the corrosive medium and consequently an increase in current density.

The ball counter face roughness affects the wear mechanism inducing a transition from sliding particles to rolling particles.

The wear scar increases as the load increases too, and this effect is accompanied by current density increase due to the enlargement of an active area for corrosion.

* Technical contribution to the $2^{\text {nd }}$ International Brazilian Conference on Tribology - TriboBR 2014, November $3^{r d}$ to $5^{\text {th }}, 2014$, Foz do Iguaçu, PR, Brazil. 


\section{Acknowledgments}

The authors are grateful to Capes_Proex, CNPq and Fapemig for financial support.

\section{REFERENCES}

1 Santandréa, R., Dissertação de Mestrado - Análise da Corrosão em Aços Inoxidáveis Ferríticos Estabilizados e com Teores Variáveis de Molibdênio, Rio de Janeiro, RJ Brasil, 1999.

2 Panossian, Z., Corrosão e Proteção Contra Corrosão em Equipamentos e Estruturas Metálicas, Vol. I e II, IPT-São Paulo, 1993.

3 Hutchings, I. M., "Tribology: Friction and Wear of Engineering Materials", CRC Press, Boca Raton, USA, 1992.

4 Karl-Heinz Zum Gahr., "Microstructure and Wear of Materials", Institute of Materials Technology, University of Siegen, Siegen, Federal Republic of Germany, 1987.

5 Wood R. J. K., D. Sun, Thakare, M. R., Rozas, A. De F., Wharton J.A., Interpretation of electrochemical measurements made during micro-abrasion-corrosion, Tribology International 43 (2010)1218-1227.

6 Bello, J. O., Wood, R. J. K., Wharton, J. A., Synergistic effects of micro-abrasioncorrosion of UNS S30403, S31603 and S32760 stainless steels Wear 263 (2007) 149159.

7 Perret, J., Boehm-Courjault, E., Cantoni, M., Mischler, S., Beaudouin A., Chitty W., Vernot J.-P., "EBSD, SEM and FIB characterisation of subsurface deformation during tribocorrosion of stainless steel in sulphuric acid", Wear 269 (2010) 383-393.

8 Garcia, I., Drees, D., Celis, J.P., "Corrosion-wear of passivating materials in sliding contacts based on a concept of active wear track area", Wear 249 (2001) 452-460.

9 Gant, A. J., Gee, M. G., May, A. T., "The evaluation of tribo-corrosion synergy for WCCo hardmetals in low stress abrasion", Wear 256 (2004) 500-516.

10 Stack, M. M., Jawanb, H., Mathew, M. T., "On the construction of micro-abrasion maps for a steel/polymer couple in corrosive environments", Tribol. Int. 38 (2005) 848-856.

11 Sinnett-Jones, P. E. Sinnett-Jones, Wharton, J. A., Wood, R. J. K., "Micro-abrasioncorrosion of a CoCrMo alloy in simulated artificial hip joint environments", Wear 259 (2005) 898-909.

12 Thakare, M. R., Wharton, J. A., Wood, R. J. K., Menger, "Investigation of micro-scale abrasion-corrosion of WC-based sintered hard metal and sprayed coating using in situ electrochemical current-noise measurements", Wear 267 (2009) 1967-1977

13 Labiapari, W. S., Alcantara, C. M., Costa H. L., Demello, J. D. B., Stainless steel as an antiwear material for the bio-fuel industry, Wear 01/2013; 302(s 1-2):1536-1545.

14 Adachi, K., Hutchings, I. M., "Wear-mode mapping for the micro-scale abrasion test", Wear 255, 2003, p23-29.

15 Williams, J.A., Hyncica, A.M., Abrasive wear in lubricated contacts, J. Phys. D: Appl. Phys. 25 1992. A81-A90.

16 Trezona, R. I., Allsopp, D. N., Hutchings, I.M., "Transitions between two-body and threebody abrasive wear: influence of test conditions in the microscale abrasive wear test", Wear 225-229, 1999, p205-214.

17 M. M. Stack, J. Rodling, M. T. Mathew, H. Jawan,W. Huang, G. Park, C. Hodge, Microabrasion-corrosion of a Co-Cr/UHMWPE couple in Ringer's solution: An approach to construction of mechanism and synergism maps for application to bio-implants, Wear 269 (2010) 376-382.

18 Pei-Qiang Wu, J.-P. Celis, Electrochemical noise measurements on stainless steel during corrosion-wear in sliding contacts, Wear 256 (2004) 480-490.

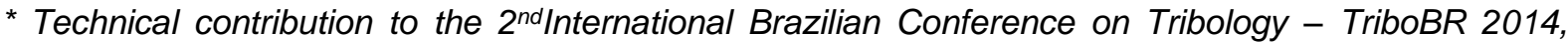
November $3^{\text {rd }}$ to $5^{\text {th }}, 2014$, Foz do Iguaçu, PR, Brazil.
} 